\title{
Comparison of CCR, Cockcroft-Gault and Mdrd Formula for the Estimation of Glomerular Filtration Rate
}

\author{
M PARVIN ${ }^{\mathrm{a}}$, MAH KHAN ${ }^{\mathrm{b}}$, M SAIEDULLAH ${ }^{\mathrm{c}}$, MR RAHMAN $^{\mathrm{d}}$, MS ISLAM ${ }^{\mathrm{e}}$, L NAZNIN $^{f}$
}

\section{Summary:}

Many organizations recommend the use of equations that provide a rapid method of assessing glomerular filtration rate (GFR) to facilitate the detection, evaluation, and management of chronic kidney diseases. Indeed, many clinical laboratories already report estimated GFR (eGFR) values whenever the serum creatinine level is measured. To compare the predictive equations for the measurement of GFR in Bangladeshi population, we measured GFR by creatinine clearance rate (CCR) and also estimated it by Modification of Diet in Renal Disease (MDRD) 4 variables equation and Cockcroft and Gault (C-G) formula in 61 Bangladeshi subjects who were referred to Armed Forces Institute of Pathology, Dhaka Cantonment for the estimation of GFR by physicians during the period of March 2011 to November 2011. Results are expressed as mean $\pm S D$ and compared by two-tailed paired t test, Bland-Altman plots for bias, precision $\left(r^{2}\right)$, receiver-operating characteristics (ROC) curve, and accuracy within 15\%, 30\% and 50\% of the measured GFR. We included 39 (63.93\%) males and 22

Introduction:

Glomerular filtration rate (GFR) is a useful marker of kidney function. Decreased GFR indicates the

a. Col. Mimi Parvin, Combined Military Hospital, Shaheed Salahuddin Cantonment, Ghatail, Tangail, Bangladesh

b. Prof. Md. Aminul Haque Khan, Professor, Department of Biochemistry, Enam Medical College, Savar, Dhaka, Bangladesh

c. Dr. Muhammad Saiedullah, Assistant Professor, Department of Applied Laboratory Sciences, Bangladesh University of Health Sciences (BUHS), Dhaka, Bangladesh

d. Dr. Muhammad Rezwanur Rahman, Associate Professor, Department of Biochemistry, Delta Medical College, Dhaka, Bangladesh

e. Major General Md. Saiful Islam, Commandant, Armed Forces Institute of Pathology (AFIP), Dhaka, Bangladesh

f. Lt. Col. Lubna Naznin, Department of Chemical Pathology, Armed Forces Institute of Pathology (AFIP), Dhaka, Bangladesh

Address of Correspondence: Col Mimi Parvin, Combined Military Hospital, Shaheed Salahuddin Cantonment, Ghatail, Tangail, Bangladesh, E-mail: drmimi708@yahoo.com

Received: 31 May, 2014

Accepted: 20 August, 2015
(36.06\%) females with mean age of $52 \pm 14$ years. The GFR measured by CCR was $61.30 \pm 37.38 \mathrm{~mL} / \mathrm{min} / 1.73 \mathrm{~m}^{2}$ and eGFR by MDRD4 and C-G were 51.26 $\pm 26.86(\mathrm{P}<0.05)$, $54.98 \pm 27.21(\mathrm{P}>0.05) \mathrm{mL} / \mathrm{min} / 1.73 \mathrm{~m}^{2}$ respectively. The bias was “ $10.55 \pm 25.34 \mathrm{~mL} / \mathrm{min} / 1.73 \mathrm{~m}^{2}$ for MDRD, “6.32 \pm 25.90 $\mathrm{mL} / \mathrm{min} / 1.73 \mathrm{~m}^{2}$ for $C-G$; precision was 0.5407 for MDRD, 0.5201 for $C-G$; the areas under the ROC curve was 0.5722 (P>0.05) for MDRD4, 0.5444 (P>0.05) for C-G. The percentages of eGFR falling within $15 \%$ and $30 \%$ of measured GFR were $30 \%$, 52\% for MDRD and 35\%, 52\% for C-G. Both MDRD4 and C-G showed positive bias at GFR $<60 \mathrm{~mL} / \mathrm{min} / \mathbf{1 . 7 3} \mathrm{m}^{2}$ and negative bias at $\mathrm{GFR}>\mathbf{6 0}$ $\mathrm{mL} / \mathrm{min} / 1.73 \mathrm{~m}^{2}$. The results indicate that Cockcroft-Gault formula is more accurate than MDRD4 equation in the overall GFR range, but MDRD4 appears to be more accurate at $\mathrm{GFR}<60 \mathrm{~mL} / \mathrm{min} / 1.73 \mathrm{~m}^{2}$.

Key words: CCR, MDRD, Cockcroft-Gault formula, Estimated GFR, eGFR in Bangladeshi population.

(J Banagladesh Coll Phys Surg 2015; 33: 207-212)

progression of chronic kidney disease (CKD) and kidney failure. ${ }^{1}$ The gold standard method for the estimation of GFR is the inulin clearance rate. ${ }^{2}$ Clearance of radioisotopes are also considered as reference methods of GFR estimation. ${ }^{3,4}$ Use of the reference methods are expensive, time-consuming and requires hospitalization; so it is unsuitable for outpatients. For the assessment of CKD, serum creatinine is most often used to predict the CKD stage. Serum creatinine is affected by factors not associated with GFR. ${ }^{5-7}$ To overcome the problems of reference methods and use of serum creatinine alone, GFR prediction equations were developed. GFR prediction equations were developed based on the data of populations that have different dietary food pattern and body muscle mass from our population. ${ }^{8,9}$ Studies carried out in populations other than the populations in whom the prediction equations for GFR were developed showed a considerable difference between measured GFR and estimated GFR. ${ }^{10,11}$ Two recent studies evaluated various GFR prediction equations in Bangladeshi population. ${ }^{12,13}$ But still it requires more studies in different settings about the use of GFR 
prediction equations in our population. The aim of this study was to measure GFR by creatinine clearance rate (CCR), estimate GFR by Modification of Diet in Renal Disease (MDRD) 4 variables equation ${ }^{8}$ and CockcroftGault (C-G) formula ${ }^{9}$ and to compare the measured GFR with eGFR to evaluate the use of these GFR prediction equations in Bangladeshi population.

\section{Materials and methods:}

This cross-sectional study was carried out in the Department of Chemical Pathology, Armed Forces Institute of Pathology (AFIP), Dhaka Cantonment, Bangladesh. We included 61 Bangladeshi subjects referred to AFIP for the estimation of GFR by physicians during the period of March 2011 to November 2011. The inclusion criterion was age $>18$ years. Exclusion criteria included diabetes mellitus, malignancies, liver, thyroid or infectious diseases at the time of recruitment, organ transplantation and pregnancy. Serum creatinine and 24-hours urinary creatinine concentrations were measured by Jaffe method using reagent and analyzer (Pentra-400) by Horiba, France. Creatinine measurement was calibrated using calibrators traceable to isotope dilution mass spectroscopy (IDMS). Creatinine clearance rate (CCR) was calculated from serum creatinine and 24-hours urinary creatinine excretion and adjusted for body surface area (BSA) ${ }^{14}$ to obtain GFR by creatinine clearance and termed as measured GFR. GFR of all patients were also calculated by the Modification of Diet in Renal Disease 4 variables which includes age, sex, ethnicity, and serum creatinine (MDRD4) equation $^{8}$ [GFR $=175 \times$ (Standardized Scr $)^{-}$ ${ }^{1.154} \times(\text { age })^{-0.203} \times 1.212$ (if black) $x 0.742$ if female] and by Cockcroft-Gault (C-G) formula ${ }^{9}\left[\mathrm{C}_{\mathrm{cr}}=0.8 \times\right.$ (140-age) $\mathrm{x}$ weight $\mathrm{x} 0.85$, if female $\mathrm{x} 1.73 / 72$ standardized $\mathrm{S}_{\mathrm{Cr}} \mathrm{x}$ BSA] and adjusted for BSA. In these equations, GFR and creatinine clearance are expressed as $\mathrm{mL} / \mathrm{min}$ per $1.73 \mathrm{~m}^{2}$, with age in years, weight in $\mathrm{kg}$, creatinine in $\mathrm{mg} /$ dL. Relationship of the measured GFR with estimated GFR was determined by linear regression (Pearson's correlation coefficient, r). For comparison, two-tailed paired $t$ test, Bland-Altman plots for bias, precision $\left(\mathrm{r}^{2}\right)$, ROC (receiver-operating characteristic) curve, sensitivity and specificity were tested by GraphPad Prism version 5.04 for Windows. For accuracy of the estimated GFR, results within $15 \%, 30 \%$ and $50 \%$ of the measured GFR were calculated.

\section{Results:}

The mean age of the study subjects was $52 \pm 14$ years. Of the total subjects, 39 (63.93\%) were male and 22 (36.06\%) were female. The mean serum creatinine was $1.7 \pm 1.1 \mathrm{mg} / \mathrm{dL}$ and 24 hours creatinine excretion was $37.03 \pm 23.19 \mathrm{mg} / \mathrm{dL}$ and $52 \%$ subjects had GFR $<60 \mathrm{~mL} /$ $\min / 1.73 \mathrm{~m}^{2}$.

The mean of measured GFR by CCR was $61.30 \pm 37.38$ $\mathrm{mL} / \mathrm{min} / 1.73 \mathrm{~m}^{2} .{ }_{\mathrm{e}}$ GFR (estimated GFR) by MDRD4 and C-G equations were $51.26 \pm 26.86$ and $54.98 \pm 27.21 \mathrm{~mL} /$ $\mathrm{min} / 1.73 \mathrm{~m}^{2}$ respectively. The correlation coefficients ( $r$ ) of measured GFR with the estimated GFR were 0.7353 $(P<0.0001)$ and $0.7212(P<0.0001)$ for MDRD4 and C-G equations respectively. The bias was " $10.55 \pm 25.34 \mathrm{~mL} /$ $\mathrm{min} / 1.73 \mathrm{~m}^{2}$ for MDRD, “ $6.32 \pm 25.90 \mathrm{~mL} / \mathrm{min} / 1.73 \mathrm{~m}^{2}$ for C-G; precision was 0.5407 for MDRD, 0.5201 for C-G; the areas under the ROC curve was $0.5722(P>0.05)$ for MDRD4, $0.5444(P>0.05)$ for C-G. The relationship of measured GFR with reciprocal of serum creatinine and serum creatinine is presented in Fig 1 and ROC is presented in Fig 2. Table I shows the comparison of
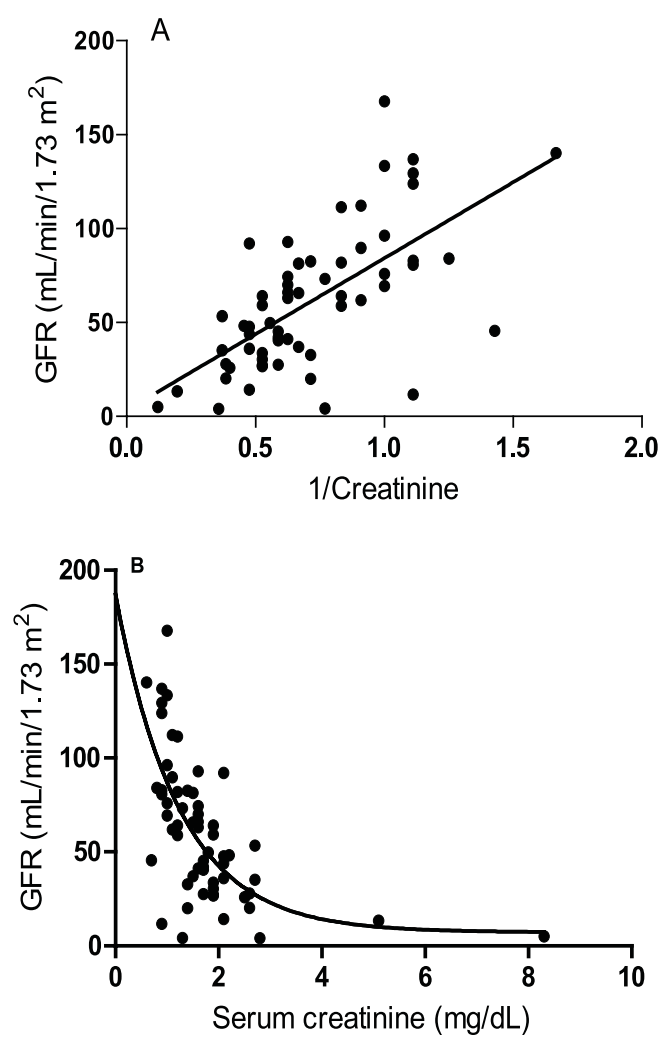

Fig.-1: Relationship of GFR with reciprocal of serum creatinine (A) and serum creatinine $(B$ 

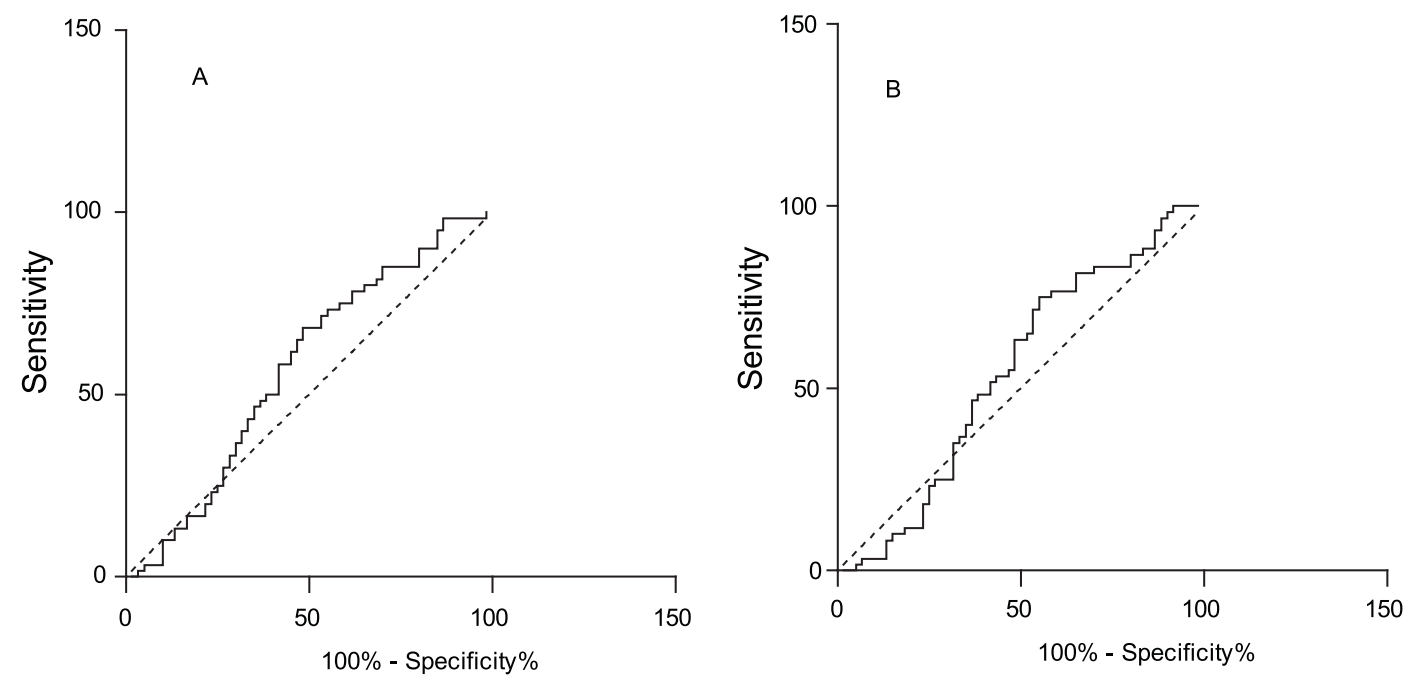

Fig.-2: Receiver-operating characteristics curve for MDRD4 (A) and C-G (B). Solid lines indicate sensitivity and broken lines indicate the line of identity

Table-I

\begin{tabular}{|c|c|c|c|}
\hline \multicolumn{4}{|c|}{ Comparison of estimated GFR with measured GFR } \\
\hline & Measured GFR & $\mathrm{GFR}_{\mathrm{MDRD} 4}$ & $\mathrm{GFR}_{\mathrm{C}-\mathrm{G}}$ \\
\hline Mean \pm SD $\left(\mathrm{mL} / \mathrm{min} / 1.73 \mathrm{~m}^{2}\right)$ & $61.30 \pm 37.38$ & $51.26 \pm 26.86 * *$ & $54.98 \pm 27.21^{\mathrm{ns}}$ \\
\hline $\operatorname{Bias}\left(\mathrm{mL} / \mathrm{min} / 1.73 \mathrm{~m}^{2}\right)$ & & “10.55 \pm 25.34 & “6.32 \pm 25.90 \\
\hline Precision, $r^{2}$ & & 0.5407 & 0.5201 \\
\hline Sensitivity & & $68.33 \%$ & $63.33 \%$ \\
\hline AUC & & $0.5722^{\mathrm{ns}}$ & $0.5444^{\mathrm{ns}}$ \\
\hline \multicolumn{4}{|l|}{ Accuracy } \\
\hline Within $15 \%$ of measured GFR & & $30 \%$ & $35 \%$ \\
\hline Within $30 \%$ of measured GFR & & $52 \%$ & $52 \%$ \\
\hline Within $50 \%$ of measured GFR & & $85 \%$ & $68 \%$ \\
\hline
\end{tabular}

$\mathrm{ns}, P>0.05 ; * *, P<0.01$

estimated GFR with measured GFR. GFR estimated by MDRD4 equation $\left(51.26 \pm 26.86 \mathrm{~mL} / \mathrm{min} / 1.73 \mathrm{~m}^{2}\right)$ and CG formula $\left(54.98 \pm 27.21 \mathrm{~mL} / \mathrm{min} / 1.73 \mathrm{~m}^{2}\right)$ were $10.55 \mathrm{~mL} /$ $\mathrm{min} / 1.73 \mathrm{~m}^{2}(P<0.01)$ and $6.32 \mathrm{~mL} / \mathrm{min} / 1.73 \mathrm{~m}^{2}(P>0.05)$ lower than mean of measured GFR $(61.30 \pm 37.38 \mathrm{~mL} / \mathrm{min} /$ $1.73 \mathrm{~m}^{2}$ ). The percentages of eGFR falling within $15 \%$ and $30 \%$ of measured GFR were $30 \%$, 52\% for MDRD and 35\%, 52\% for C-G. Both MDRD4 and C-G showed positive bias at $\mathrm{GFR}<60 \mathrm{~mL} / \mathrm{min} / 1.73 \mathrm{~m}^{2}$ and negative bias at GFR $>60 \mathrm{~mL} / \mathrm{min} / 1.73 \mathrm{~m}^{2}$. The bias was “ $10.55 \pm 25.34 \mathrm{~mL} / \mathrm{min} / 1.73 \mathrm{~m}^{2}$ for MDRD, “ $6.32 \pm 25.90 \mathrm{~mL} /$ $\min / 1.73 \mathrm{~m}^{2}$ for $\mathrm{C}-\mathrm{G}$
Comparison of eGFR with measured GFR at $<60 \mathrm{~mL} /$ $\mathrm{min} / 1.73 \mathrm{~m}^{2}$ and at $>60 \mathrm{~mL} / \mathrm{min} / 1.73 \mathrm{~m}^{2}$ is shown in Fig 3 . Mean values were $32.57 \pm 15.63$, 35.85 \pm 19.06 and $40.97 \pm 19.52 \mathrm{~mL} / \mathrm{min} / 1.73 \mathrm{~m}^{2}$ for measured GFR, MDRD4 and C-G respectively at measured GFR $<60 \mathrm{~mL} / \mathrm{min} / 1.73$ $\mathrm{m}^{2}$. MDRD4 eGFR was $3.28 \mathrm{~mL} / \mathrm{min} / 1.73 \mathrm{~m}^{2}$ higher $(P>0.05)$ and C-G GFR was $8.39 \mathrm{~mL} / \mathrm{min} / 1.73 \mathrm{~m}^{2}$ higher $(P<0.05)$ than measured GFR at $<60 \mathrm{~mL} / \mathrm{min} / 1.73 \mathrm{~m}^{2}$. On the other hand, at measured GFR e" $60 \mathrm{~mL} / \mathrm{min} / 1.73 \mathrm{~m}^{2}$, mean values were $92.01 \pm 28.13,66.69 \pm 24.93$ and $69.96 \pm 26.49 \mathrm{~mL} / \mathrm{min} / 1.73 \mathrm{~m}^{2}$ for measured GFR, MDRD4 and C-G respectively. MDRD4 eGFR was $25.32 \mathrm{~mL} / \mathrm{min} /$ 

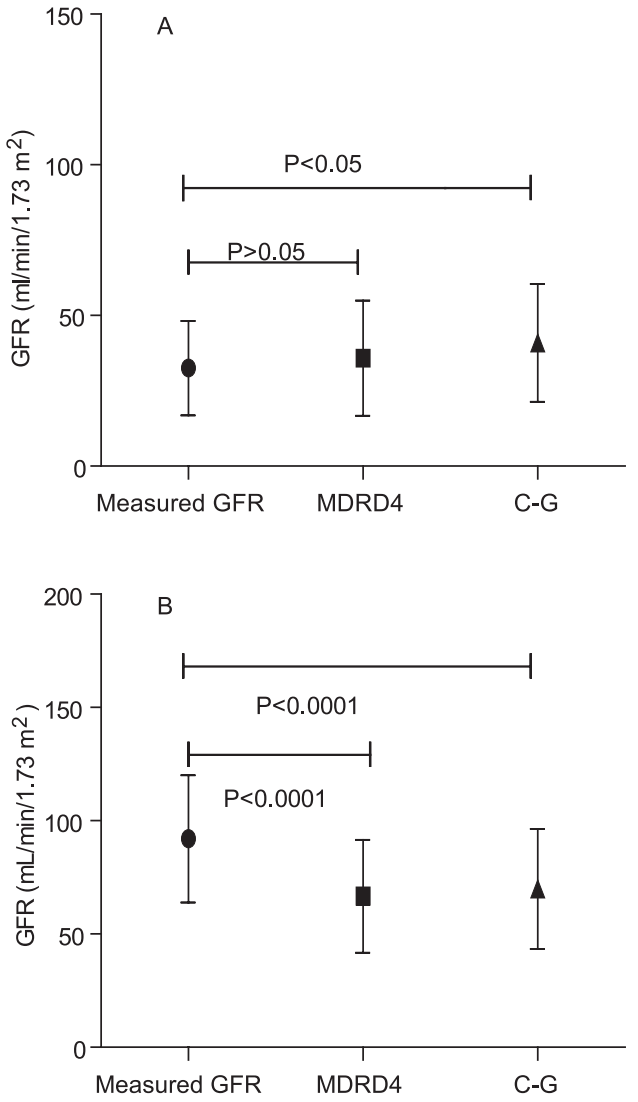

Fig.-3: Comparison of eGFR with measured GFR at measured GFR $<60 \mathrm{~mL} / \mathrm{min} / 1.73 \mathrm{~m}^{2}$ (A) and at GFR e"60 $\mathrm{mL} / \mathrm{min} / 1.73 \mathrm{~m}^{2}(B)$

$1.73 \mathrm{~m}^{2}$ lower $(P<0.0001)$ and C-G GFR was $22.05 \mathrm{~mL} /$ $\mathrm{min} / 1.73 \mathrm{~m}^{2}$ lower $(P<0.0001)$ than measured GFR.

\section{Discussion:}

Accurate assessment of renal function is important for diagnostic and intervention purposes, proper medication dosing and decision-making to start dialysis in appropriate stage in CKD patients. The filtration markers (inulin, EDTA, iothalamate, iohexol, DTPA etc) used in the reference methods of GFR measurement are costly and cumbersome to use. Radioactive markers require special handling and disposal. So these standard methods are unsuitable in clinical practice. Instead of standard methods, prediction equations based on demographic characteristics, such as age, gender, race and weight, and biochemical indices, including serum creatinine, urea, and albumin are being used to predict GFR. An estimating equation is derived with the use of regression techniques to model the observed relation between the serum level of the marker and the measured GFR in a study population. ${ }^{15}$

In this study, estimated GFR by MDRD4 equation and C-G formula statistically significantly correlated with measured GFR. Though both equations showed negative bias with measured GFR, estimated GFR by MDRD4 is significantly lower and GFR estimated by C$G$ showed no significant difference with measured GFR (Table I). The precision, sensitivity, AUC are better for MDRD4 than C-G. Accuracy within 15\% of measured GFR is better for C-G, similar within $30 \%$ and better for MDRD4 within 50\% of measured GFR. However, comparison of eGFR below and above $60 \mathrm{~mL} / \mathrm{min} / 1.73$ $\mathrm{m}^{2}$ of measured GFR showed that both MDRD4 and CG showed positive bias at GFR $<60 \mathrm{~mL} / \mathrm{min} / 1.73 \mathrm{~m}^{2}$ and both showed negative bias at GFR e"60 mL/min/1.73 $\mathrm{m}^{2}$. A consistent finding of this study was the strong negative association between bias and GFR. The higher the GFR, the more likely it would be underestimated regardless of the equation used. However, MDRD4 eGFR is closer to measured GFR at GFR $<60 \mathrm{~mL} / \mathrm{min} / 1.73 \mathrm{~m}^{2}$. In this study, MDRD equation showed a sustained advantage in estimating renal function that was more evident as GFR declined which is similar to the study done by Darren Lee et al. ${ }^{16}$

Most of the study subjects of MDRD4 study had GFR $<60 \mathrm{~mL} / \mathrm{min} / 1.73 \mathrm{~m}^{2}$ and it is less accurate when GFR is above $60 \mathrm{~mL} / \mathrm{min} / 1.73 \mathrm{~m}^{2} .^{8}$ The underestimation of these formulas at GFR $>60 \mathrm{~mL} / \mathrm{min} / 1.73 \mathrm{~m}^{2}$ is common. ${ }^{1,17-19}$ There are several possible explanations for reports of less accuracy of higher GFR estimates.

- Inter-laboratory variation in calibration of serum creatinine assays, which has a larger effect at higher GFR levels. This is likely an important reason of wide variations among published studies.

- Greater biologic and measurement variability of GFR at higher values; and

- Limitations of generalizing an equation developed in one population to another population.

These are the reasons why most clinical laboratories recommended not to report GFR estimates as numerical 
values when MDRD4 eGFR is above $60 \mathrm{~mL} / \mathrm{min} / 1.73$ $\mathrm{m}^{2} .8,15,21$

In this study we found that at GFR $<60 \mathrm{~mL} / \mathrm{min} / 1.73 \mathrm{~m}^{2}$, the MDRD4 appears to be more accurate than $\mathrm{C}-\mathrm{G}$ with positive bias. This result is consistent with the previous studies done in Bangladeshi population ${ }^{12,13}$ in which most of the study subjects had GFR $<60 \mathrm{~mL} / \mathrm{min} / 1.73 \mathrm{~m}^{2}$ and also consistent with the work carried out in other South Asian countries like Pakistan ${ }^{11}$ and India. ${ }^{20}$

\section{Conclusion:}

Estimation of GFR (eGFR) is now a powerful decision making tool in CKD although all GFR estimating equations have some limitations. Since reporting of eGFR delivers important information to the clinicians at little incremental cost; routine reporting is desirable even without request from the physicians whenever serum creatinine is measured. In this study, we found MDRD4 equation more accurate at GFR $<60 \mathrm{~mL} / \mathrm{min} / 1.73 \mathrm{~m}^{2}$ and C-G equation more accurate at GFR e" $60 \mathrm{~mL} / \mathrm{min} / 1.73$ $\mathrm{m}^{2}$. So it needs to be cautious while estimating GFR by using the prediction equations. We also recommend more studies in our population with larger sample size to compare prediction equations against GFR measured by gold standard method.

\section{References:}

1. Bostom AG, Kronenberg F, Ritz E. Predictive performance of renal function equations for patients with chronic kidney disease and normal serum creatinine levels. J Am Soc Nephrol 2002; 13:2140-4.

2. Shannon JA, Smith HW. The excretion of inulin xylose, and urea by normal phlorizinized man. J Clin Invest 1935; 14:393-401.

3. Sjoberg S, Hellsten S, Almen T, Golman K, Gronberg T. Estimating kidney function during urography. Comparison of contrast medium clearance and simultaneous 51CrEDTA clearance. Acta Radiol 1987; 28:587-92.

4. Piepsz A, Denis R, Ham HR, Dobbeleir A, Schulman C, Erbsmann F. A simple method for measuring separate glomerular filtration rate using a single injection of 99mTcDTPA and the scintillation camera. J Pediatr 1978; 93:769-74.

5. MacAulay J, Thompson K, Kiberd BA, Barnes DC, Peltekian KM. Serum creatinine in patients with advanced liver disease is of limited value for identification for moderate renal dysfunction: are the equations for estimating renal function better? Can J Gastroenterol 2006; 20:521.

6. Wilson DM, Bergert JH, Larson TS, Liedtke RR. GFR determined by nonradiolabeled using capillary electrophoresis. Am J Kidney Dis 1997; 30:646-52.

7. Ma YC, Zuo L, Chen JH, Luo Q, Yu XQ, et al. Modified glomerular filtration rate estimating equation for Chinese patients with chronic kidney disease. J Am Soc Nephrol 2006; 17:2937-44.

8. Levey AS, Coresh J, Greene T, Stevens LA, Zhang YL, Hendriksen S, et al. Chronic Kidney Disease Epidemiology Collaboration. Using standardized serum creatinine values in the modification of diet in renal disease study equation for estimating glomerular filtration rate. Ann Intern Med 2006; $145: 247-54$.

9. Cockcroft DW, Gault MH. Prediction of creatinine clearance from serum creatinine. Nephron 1976; 16: 31-41.

10. Eastwood JB, Kerry SM, Rhule JP, Micah FB, Antwi S, Boa FG, et al. Assessment of GFR by four methods in adults in Ashanti, Ghana: the need for an eGFR equation for lean African populations. Nephrol Dial Transplant 2010; 25:2178-87.

11. Jafar TH, Schmid CH, Levey AS. Serum creatinine as marker of kidney function in South Asians: a study of reduced GFR in adults in Pakistan. J Am Soc Nephrol 2005; 16:1413-9.

12. Saiedullah M, Rahman MR, Khan MAH, Hayat S, Begum S. Comparison of GFR by creatinine clearance with estimated GFR by various prediction equations in a Bangladeshi population. J Life Sciences USA 2012; 6(3):330-4.

13. Saiedullah M, Begum S, Rahman MR, Khan MAH, Hayat S, Kamaluddin SM, Shaheen MAH. Evaluation of CKDEPI and MDRD prediction equations for estimation of GFR in lean and obese Bangladeshi subjects. J. Sci. Res. 2013; 5(1): 207-13.

14. DuBois D, DuBois EF. A formula to estimate the approximate surface area if height and weight are known. Arch Intern Med 1916; 17:863-71.

15. Stevens LA, Coresh J, Greene T and Levey AS. Assessing kidney function- Measured and estimated glomerular filtration rate. New Eng J Med 2006; 354:2473-83.

16. Lee D, Levin A, Roger SD, McMahon LP. Longitudinal analysis of performance of estimated glomerular filtration rate as renal function declines in chronic kidney disease. Nephrol Dial Transplant 2009; 24: 109-16. 
17. Lewis J, Agodoa L, Cheek D, Greene T, Middleton J, O’Connor D, et al; for the African-American study of Hypertension and Kidney Disease. Comparison of crosssectional renal function measurements in AfricanAmericans with hypertensive nephrosclerosis and of primary formulas to estimate glomerular filtration rate. Am J Kidney Dis 2001; 38:744-53.

18. Froissart M, Rossert J, Jacquot C, Paillard M, Houillier P. Predictive performance of the Modification of Diet in Renal Disease and Cockcroft-Gault equations for estimating renal function. J Am Soc Nephrol 2005; 16:763-73.
19. Rule AD, Larson TS, Bergstralh EJ, Slezak JM, Jacobsen SJ, Cosio FG. Using serum creatinine to estimate glomerular filtration rate: Accuracy in good health and in chronic kidney disease. Ann Intern Med 2004; 41:92937.

20. Srinivas S, Annigeri RA, Mani MK, Rao BS, Kowdle PC, Seshadri R. Estimation of glomerular filtration rate in South Asian healthy adult kidney donors. Nephrology (Carlton). 2008; 13:440-6.

21. Levey AS, Stevens LA, Hostetter T. Automatic reporting of estimated glomerular filtration rate - Just what the doctor ordered. Clinical Chemistry 2006; 52:2188-93. 